\title{
Evaluation of Community Participation in the Development of Urban Settlement Case Study: City of Dili, East Timor
}

\author{
${ }^{1}$ Jose Agostinho Moniz. \\ ${ }^{2}$ Purwanita Setijanti. \\ ${ }^{3}$ Muhammad Faqih. \\ Departement of Architecture - Housing and Settlement. \\ Institut Teknologi Sepuluh Nopember (ITS) Surabaya, Indonesia
}

\begin{abstract}
The city of Dili is considered as essential transit access for the country because of its seaport as well as international airport. Dili potentially can grow into densely populated area compared to other districts in Timor - Leste, which is indicated by the spreading of slums.

Slums in Dili district are located in five villages, or commonly known as "Suco", namely Suco Caicoli, Suco Colmera, Suco Vila Verde, Suco Mascarenhas, and Suco Motael. Slum in Dili can be considered into urban slums which categorized into mild and moderate slums (Ministério da Administração Estatal Timor-Leste 2014).

Improvement of settlement quality is easier if it is started from the internal aspect of the people living in the settlement, especially their participation. The purpose of community participation is to obtain useful inputs and perceptions of citizens and public interest in order to improve the quality of environmental related decision-making (Canter, 1977 in Horoepoetri, 2009). It is being questionable for their participation since the conditions of existing settlements do not meet the quality of life, which is proved by the growth of slums).
\end{abstract}

The research methods used is descriptive research. Descriptive research is conducted by creating description, depicted in systematic, factual and accurate about facts, properties and the connection among investigated phenomena. The main interest is on how community participation could be used in urban improvement programs which is based on community participation. The case area is the city of Dili (sub district vera-cruz), namely: Suco Caicoli, Suco Colmera, Suco Vila Verde, Suco Motael, Suco Mascarenhas and Suco.

The research results show that community participation in the improvement and maintenance of the settlement will not succeed if poverty is still being existed (they are unable to participate in donations or giving materials). Community unawareness towards their urban living environment shown by the existence of urban-slum dwellers. However, they believe that this is common situation because of poor level education. In fact, it is potentially beneficial that the proportion of male is bigger than female, so that they could take part in rehabilitation and improvement of settlement through their membership in informal organization.

Keywords - City of Dili, Community Development, Housing Development.

\section{INTRODUCTION}

City as part of population growth is experiencing rapid changes due to the attraction of developing population. The development of city will be faster if supported by the natural resources and infrastructure. The city will be quickly developed if it is located on a crowded shipping lanes supported by hinterland area. Rapid urban development should be supported by adequate infrastructures. Lack of infrastructures can lead into some urban issues due to the imbalance between human needs and environmental capacity. To overcome this, urban development should take into account the needs and scale of urban service needs in order to achieve sustainability.

Development of city is often indicated by the availability of facilities as well as infrastructure. Farmland and green open space are changed into commercials, housing, landmark, industry and others which cause the degradation of environment. Due to the disruption of the stability of urban ecosystems, some natural disruption are occured, including rising temperatures, flooding, noise, groundwater contamination, polluted drinking water, drinking water containing heavy metals, and air pollution.

The city of Dili is considered as essential transit access for the country because of its seaport as well as international airport. Dili potentially can grow into densely populated area compared to other districts in Timor - Leste, which is indicated by the spreading of slums. Slums in Dili district are located in five villages, or commonly known as "Suco", namely Suco Caicoli, Suco Colmera, Suco Vila Verde, Suco Mascarenhas, and Suco Motael. Slum in Dili can be considered into urban slums which categorized into mild and moderate slums (Ministério da Administração Estatal Timor-Leste 2014).

Slum areas arise due to the large number of densely housing in the narrow alleys. Moreover, there are also several densely populated boarding houses for migrant workers around the city of Dili. This situation leads to decreasing of healthy settlement which also reducing the quality of life both in terms of the living environment and public health (Ministério da Administração Estatal TimorLeste 2014).

Like in major developing cities in Republic of Democratica de Timor-Leste (RDTL), the main cause of settlement problems in the city of Dili is rapid population growth. Besides, high urbanization rates also make it difficult to control existing settlement areas. The growth of these settlement areas are in great need of improvements in facilities, utilities and infrastructure. 
Community participation is the main factor in planning green public spaces. In fact, tahe state of community participation is low and not yet succeed because of lack commnication between local government and society. Thus the government is more likely to use top down or decentralize planning rather than bottom ups that accommodate the public interest. This can be seen from the percentage of community participation who previously had received the information about government planning only reached 20 percent, only a small number of people who ever asked for opinion (public hearings) of 28 percent. The role of the community is still unclear, so there is a remarkable difference between external factors, which is community participation in management of green open space (Ministério da Administração Estatal Timor-Leste 2014). Comparing with previous research conducted by Breuste (2004) in Judge, Dkk, 2008 planning will be worked better by involving the society together. Branch (1970) in Judge, et al (2008) emphasized that in the management of green open spaces of the city, it should be evaluated continuously and flexibly. In certain areas there is a government's authority to plan green open spaces but on a wider area of community involvement it is obligatory that such planning fits the needs of the community to address the complexities of urban growth.

The purpose of community participation since the planning stage is to generate useful inputs and perceptions of citizens and public interest in order to improve the quality of environmental decision-making (Canter, 1977 in Horoepoetri, 2009).

Currently, there is still lack study in measuring success rate of community participation in village improvement programs. Thus, it is urgently needed to analyze in detailed survey, which is aimed in this research. The evaluation phase of community participation in this research was conducted by assessing community's evaluation of participation in the settlement improvement programs in Dili, particularly the sub-district of Vera-Cruz and how the formulation of urban settlement improvement based on community participation to solve the slum settlement problem in Dili urban village.

\section{LITERATURE REVIEW}

\section{A. Improper settlement and good quality settlement}

Settlement derived from English word which means housing or human settlement. Slum is the general description of poor attitude and behavior in terms of standard of living and middle income category. In other words, slums can be interpreted as symbols by upper class for describing unsettled low income level (Kurniasih, 2007).

According to Adriasih (2004), slum is a housing in which the living conditions are very crowded, lack of proportional standard of occupants. It is just used as a place to sleep and rest and to protect from sun and rain in temporary buildings, disrepair without planning, poor infrastructure (toilets, clean water, sewerage, electricity, alley, dirty environment and become source of disease), lack of social facilities (schools, houses of worship, clinics), generally occupied by non-permanent inhabitants working on non-formal business, non-resident land, poorly educated, occupants often not listed as local residents (migrants from outside the region), high risk of floods, fires and spreading disease. Johan Silas in Titisari and Kurniawan (1999), explains that the main criteria for determining slum / marginal settlements are:

1. It is located on illegal settlement, with sub-standard physical condition

2. Low income resident (poor)

3. No access to public facilities

4. Unwanted presence by the public (except those concerned).

Based on those Silas criteria, the aspect of legality have to be taken into account to categorize slum, in addition to poor environmental quality.

According to Sinulingga (2005) the characteristics of slums are:

1. The population is very dense between $250-400$ inhabitants / Ha. The opinion of urban experts states that if the density of an area has reached 80 people / $\mathrm{Ha}$ then the problem arises due to this density. Housing is no longer meet the minimum standard of physiological, psychological and disease protection.

2. Narrow streets can still be crossed by four-wheeled vehicles, and because of the narrowness sometimes this road is hidden behind the roofs of houses that have intersected with each other.

3. Drainage system facilities are inadequate, and even there is no drainage system in certain road network, so if that it is easily flooded.

4. Sanitation facilities are inadequate, that some of people use drainage system near the house as their sewage system.

5. Lack of water supply facilities, so that they take shallow groundwater, rainwater or buy clean water.

6. Lack of good building arrangement as well as nonpermanent builing

7. The ownership of land rights is often legal, meaning that the status of the land is still a state land and the owners have no right

According to Krista (2009) an assessment standard used in building healthy and ecological house is as follows:

1. Considering the availability of facilities and infrastructure services.

2. Creating green open space between constructed area.

3. Considering material life cycle and using renewable materials.

4. Using natural air ventilation inside the building.

5. Avoids soil moisture rises into building construction.

6. Selecting layers of wall and ceiling surfaces that are able to drain water vapor.

7. Ensure continuity in the structure as the correlation between materials life span and constrution structures.

8. Considering shape or proportion of the room.

9. Ensuring that the building will not bring any problems. 


\section{B. Definition of Community Participation}

According to Mikkelsen (2003) participation is involvement in developmen of personal qualification, life and the society. Involvement means providing and giving both energy and thought (Wibisanan, 1989). The forms of involvement are: (1) Decision-making; (2) Implementing the program; (3) Enjoy the benefits of the program; and (4) Evaluate the program.

\section{Type of Community Participation}

Community participation can be seen through the participation of individuals in the joint activities undertaken within the community. The involvement or participation of the individual can be measured on the scale suggested by Chapin and Goldhamer (in Slamet 1994: 82-89) Chapin reveals that the scale of participation can be derived from assessments in social role-level criteria:

1. Membership in organizations or social institutions

2. Attendance at meetings

3. Pay contributions / donations

4. Membership in the stewardship

5. Position of members in the stewardship

Measurement of community participation begins with how the community is actually involved in the real activities that constitute the embodiment of the program outlined in physical activity. Therefore, the measurement of community participation is the extent to which the community is able to contribute in every activity of the institution concerned. Community donations can be in the form of money, energy, and can also be material or goods. People can contribute from either one of these three, or all of them. Such participation varies in each region depending on community characteristics (Slamet, 1994).

\section{Factors in Community Participation}

Korten, 1983 in Setiawan, (2005) mentioned that there are factors influencing community participation in city development. These factors can be grouped into two categories namely internal factors and external factors. Internal factors are factors within the community that is influential in community participation programs, while external factors are coming from outside the community, and this will cover two aspects concerning macro socialpolitical system in which the community is located.

\section{E. Function of Community Participation}

Achmad Santosa (1990) has also summarized the benefitd of community participation, as follows:

1. Establish a responsible society

2. Improve learning process

3. Taking out feelings of isolation

4. Increase support and acceptance of government plans;

5. Creating political awareness

6. Decisions of community participation reveal the needs and desires of the community

7. Be a source of useful information

8. It is a commitment of the democratic system

\section{METHODOLOGY}

\section{A. Variables}

The variables used in this study are related with satisfaction of infrastructure services that describing availability of infrastructure and services. Furthermore, it is going to be assessed on the level of participation (in order to determine the factors that influence community participation). Both of these assessment results are used as the formulation basis of rehabilitation and maintenance of settlements.

\begin{tabular}{|c|c|c|}
\hline No & Variable & Indicator \\
\hline 1. & $\begin{array}{l}\text { Community satisfaction towards } \\
\text { the availability of urban } \\
\text { infrastucture }\end{array}$ & $\begin{array}{l}\text { a. Transportation } \\
\text { b. Education } \\
\text { c. House of worship } \\
\text { d. Commercials and services } \\
\text { e. Health } \\
\text { f. Governance } \\
\text { g. Public facilities and park } \\
\text { h. Road network } \\
\text { i. Telephone } \\
\text { j. Electricity } \\
\text { k. Water supply } \\
\text { 1. Drainage } \\
\text { m. Sanitation } \\
\text { n. Municipal } \\
\quad \text { management }\end{array}$ \\
\hline 2. & $\begin{array}{l}\text { Evaluation of community } \\
\text { participation level }\end{array}$ & $\begin{array}{l}\text { a. Membership of certain } \\
\text { association } \\
\text { b. Attendance in every } \\
\text { meeting } \\
\begin{array}{l}\text { c. Donation } \\
\text { level }\end{array}\end{array}$ \\
\hline
\end{tabular}

\section{B. Study Case}

This research will be conducted in Dili City (Sub District Dili), Vera-cruz district. Selection of this location is based on several considerations, as follows:

1. Vera-Cruz sub-district is the center of administrative of the Republic of Democratica de Timor-Leste (RDTL)

2. Based on the primary observations, there is rapid physical development and high population growth in the city of Dili

\section{Sample}

Data gathered by determining sample from the existing population. Sampling will be based on the number of respondents referring to the initial survey as follows:

1. Dili city government apparatus whose numbers are determined by purposive sampling technique ie apparatus involved with the formulation process of Dili city government policy that is:

- Head of sub-district Vera-Cruz

- Local government including District Secretary (administrador Sub District) and heads of sub-district Dili

- Sefi do Suco (head of village) in selected village

2. People living in Dili (considering the capability of the researcher without ignoring representative number of population). The number of respondents is set by 200 people. 


\section{Methods of Analysis}

Data is collected and analyzed by using quantitative descriptive analysis to get an overview of community participation as the guideline for establishing government policy in the development of Dili. Analysis is performed within the scope as follows:

1. Analysis of the level of community appraisal of housing facilities

2. Community Participation Level Analysis in Dili City Settlements Improvement

3. Analysis of the condition of Settlement Improvement in the Study Area

4. Evaluating the Concept of Community Participation in Settlement Improvement

Analytical methods conducted in this study include descriptive qualitative analysis based on the results of questionnaires interpretation distributed in the sample population. Descriptive qualitative analysis is an assessment on some parameters including community participation, influence factors and its impact on the improvement of the settlement.

\section{DISCUSSION}

City of Dili is currently serves a the only import and export entry point for goods and services for the state of East Timor. City of Dili located in great spot because of the existence of seaport as well as the airport which have more than $2 \mathrm{~km}$ runway. Development of infrastructure in Dili is growing rapidly as a result of the government effort in improving East Timor by providing various facilities and infrastructure, government offices, highways, telecommunication network, and public facilities.

Public transportation network in the city of Dili are motor vehicles such as Mikrolet (mini bus), taxi, bus, while bus and Angguna (multi transport) used to connect all the inland districts. Moreover, in District We'quci and Atauro there are also government subsidized ferry boats with daily payments to connect two-separated community within Dili capital.

Higher education and academy or university remains only in the city of Dili, consisting of one state university, two private universities and five private high schools. This condition makes Dili increasingly crowded because all the youth who are studying at the university are concentrated in the city of Dili. City density also has negative social impacts such as congestion, juvenile delinquency and immoral behavior, due to lack of law enforcement.

The city of Dili is in the ongoing phase of development in order to organize a city that can provide security and comfort to its residents who live in the city, as well as being a state capital.

A. Community satisfaction towards urban insfrasctructure and public facilities

\section{1) Transportation}

Transportation mode commonly used by the people of Dili are divided into land and sea based-transportation network.
TABLE II. COMMUNITY SATISFACTION TOWARDS THE AVAILABILITY

\begin{tabular}{|l|l|c|l|}
\hline No & \multicolumn{1}{|c|}{ EF PUBLIC TRANSPORTATION } & $\begin{array}{c}\text { Number of } \\
\text { Respondents }\end{array}$ & $\begin{array}{c}\text { Percentage } \\
\%\end{array}$ \\
\hline 1 & Satisfactory & 70 & 35 \\
\hline 2 & Good & 50 & 25 \\
\hline 3 & Fair & 50 & 25 \\
\hline 4 & Poor & 30 & 15 \\
\hline & Total & 200 & 100 \\
\hline
\end{tabular}

\section{2) Education}

The educational facilities in the study area are formal education and informal education facilities such as TK (eskola Infantil), Primary School (Eskola Presekundaria), Junior High School (Eskola Primaria), Senior High School (Eskola sekundaria), university (Universidade), and informal education including foreign language center and computers courses.

TABLE III. COMMUNITY SATISFACTION TOWARDS THE AVAILABILITY OF EDUCATION SERVICES IN SUB DISTRICT VERA-CRUZ DILI

\begin{tabular}{|c|c|c|c|}
\hline No & Evaluation & $\begin{array}{c}\text { Number of } \\
\text { Respondents }\end{array}$ & Percentage \% \\
\hline 1 & Satisfactory & 30 & 15 \\
\hline 2 & Good & 40 & 20 \\
\hline 3 & Fair & 64 & 32 \\
\hline 4 & Poor & 66 & 33 \\
\hline & Total & 200 & 100 \\
\hline
\end{tabular}

3) House of worship

Pada umumnya semua golongan kepercayaan yang ada di district Dili sudah memiliki sarana peribadatan sesuai kepercayaan masing - masing , pemerintah Timor- Leste sendiri setiap tahun anggaran menyediakan anggaran khusus untuk sarana peribadatan bagi semua golongan kepercayaan.

In general, all of the religion groups in Dili district have their own worship facilities. Moreover, East Timor government provides special budget for maintenance in all religion place of worship.

TABLE IV. COMMUNITY SATISFACTION TOWARDS THE AVAILABILITY OF HOUSE OF WORSHIP

\begin{tabular}{|c|c|c|c|}
\hline No & Evaluation & $\begin{array}{c}\text { Number of } \\
\text { Respondents }\end{array}$ & $\begin{array}{c}\text { Percentage } \\
\%\end{array}$ \\
\hline 1 & Satisfactory & 30 & 15 \\
\hline 2 & Good & 40 & 20 \\
\hline 3 & Fair & 70 & 35 \\
\hline 4 & Poor & 60 & 30 \\
\hline & Total & 200 & 100 \\
\hline
\end{tabular}

\section{4)Commercials and services}

The commercial facilities in the study area consist of stalls, shops and markets. Kiosk / stalls in the residential area (subdistrict Vera-Cruz) is spread throughout the city of Dili, kiosks / stalls in the study area include selling food and beverages, fruits, handicrafts, as well as household appliances and construction materials. 
TABLE V. COMMUNITY SATISFACTION TOWARDS THE AVAILABILITY OF COMMERCIALS AND SERVICES

\begin{tabular}{|c|c|c|c|}
\hline No & Evaluation & $\begin{array}{c}\text { Number of } \\
\text { Respondents }\end{array}$ & $\begin{array}{c}\text { Percentage } \\
\%\end{array}$ \\
\hline 1 & Satisfactory & 70 & 35 \\
\hline 2 & Good & 80 & 40 \\
\hline 3 & Fair & 30 & 15 \\
\hline 4 & Poor & 20 & 10 \\
\hline & Total & 200 & 100 \\
\hline
\end{tabular}

\section{5) Health Care}

Based on the observation, all study areas already have health care facilities equipped with doctors as well as some nurses.

TABLE VI. COMMUNITY SATISFACTION TOWARDS THE AVAILABILITY OF HEALTH CARE FACILITIES

\begin{tabular}{|c|c|c|c|}
\hline No & Evaluation & $\begin{array}{c}\text { Number of } \\
\text { Respondents }\end{array}$ & $\begin{array}{c}\text { Percentage } \\
\%\end{array}$ \\
\hline 1 & Satisfactory & 70 & 35 \\
\hline 2 & Good & 60 & 30 \\
\hline 3 & Fair & 50 & 25 \\
\hline 4 & Poor & 20 & 10 \\
\hline & Total & 200 & 100 \\
\hline
\end{tabular}

\section{6) Government Offices \& Institutions}

Based on the observation, study area is the center of the government of the Democratic Republic of Timor-Leste. Therefore, most of the government offices and institutions are located in the city center, each sede Suco (head of village office) has performed good services for the community.

TABLE VII. COMMUNITY SATISFACTION TOWARDS THE AVAILABILITY OF GOVERNMENT INSTITUTION

\begin{tabular}{|c|c|c|c|}
\hline No & Evaluation & $\begin{array}{c}\text { Number of } \\
\text { Respondents }\end{array}$ & $\begin{array}{c}\text { Percentage } \\
\%\end{array}$ \\
\hline 1 & Satisfactory & 70 & 35 \\
\hline 2 & Good & 80 & 40 \\
\hline 3 & Fair & 30 & 15 \\
\hline 4 & Poor & 20 & 10 \\
\hline & Total & 200 & 100 \\
\hline
\end{tabular}

\section{7) Public facilities and urban green open space}

Public facilities and green open space (RTH) can be observed that there is one stadium located in Suco Caicoli where this stadium is the only stadium owned by East Timor, one badminton court, one general sports court (GOR) while in Suco Colmera there is one city park namely Jardim (park) Cinco de Maio.

TABLE VIII. COMMUNITY SATISFACTION TOWARDS THE AVAILABILITY OF PUBLIC FACILITIES AND URBAN GREEN OPEN SPACES

\begin{tabular}{|c|c|c|c|}
\hline No & Evaluation & $\begin{array}{c}\text { Number of } \\
\text { Respondents }\end{array}$ & $\begin{array}{c}\text { Percentage } \\
\%\end{array}$ \\
\hline 1 & Satisfactory & 40 & 20 \\
\hline 2 & Good & 30 & 15 \\
\hline 3 & Fair & 60 & 30 \\
\hline 4 & Poor & 70 & 35 \\
\hline & Total & 200 & 100 \\
\hline
\end{tabular}

\section{8) Road network}

Road network in Dili sub-district neighborhood (sub District Vera-Cruz) consist of roads made of cement and paved roads. The roads at the study sites vary in width ranging from $3 \mathrm{~m}$ to $12 \mathrm{~m}$.

TABLE IX. COMMUNNITY SATISFACTION TOWARDS ROAD NETWORK

\begin{tabular}{|l|l|c|l|}
\hline No & \multicolumn{1}{|c|}{ Evaluation } & $\begin{array}{c}\text { Number of } \\
\text { Respondents }\end{array}$ & Percentage \% \\
\hline 1 & Satisfactory & 60 & 30 \\
\hline 2 & Good & 70 & 35 \\
\hline 3 & Fair & 40 & 20 \\
\hline 4 & Poor & 30 & 15 \\
\hline & Total & 200 & 100 \\
\hline
\end{tabular}

\section{9) Telephone}

$80 \%$ people of Dili (sub District Vera-cruz) owns a mobile phone. Telephone is used rarely by some of them because they find that phone cellular is way more effective to be used.

Dili has three communications networks provider, which are Timor Telekom in cooperation with Portugal, Telemor in cooperation with Vietnam, and Telkomsel in cooperation with PT Telkom Indonesia.

TABLE X. COMMUNNITY SATISFACTION TOWARDS TELEPHONE

\begin{tabular}{|c|l|c|l|}
\hline No & Evaluation & $\begin{array}{c}\text { Number of } \\
\text { Respondents }\end{array}$ & $\begin{array}{c}\text { Percentage } \\
\%\end{array}$ \\
\hline 1 & Satisfactory & 60 & 30 \\
\hline 2 & Good & 70 & 35 \\
\hline 3 & Fair & 40 & 20 \\
\hline 4 & Poor & 30 & 15 \\
\hline & Total & 200 & 100 \\
\hline
\end{tabular}

\section{0) Electricity}

Based on survey results, all housing and residential are equipped with power grid, with the main source of electricity is the state electricity company (PLN). TABLE XI. COMMUNNITY SATISFACTION TOWARDS ELECTRICITY

\begin{tabular}{|c|c|c|c|}
\hline No & Evaluation & $\begin{array}{c}\text { Number of } \\
\text { Respondents }\end{array}$ & $\begin{array}{c}\text { Percentage } \\
\%\end{array}$ \\
\hline 1 & Satisfactory & 90 & 45 \\
\hline 2 & Good & 110 & 55 \\
\hline 3 & Fair & 10 & 0,5 \\
\hline 4 & Poor & - & - \\
\hline & Total & 200 & 100 \\
\hline
\end{tabular}

\section{1) ater Supply}

Based on the survey in the study area that people have used the source of clean water from local utility (PDAM) but there are some residents who use water from excavation well because of inadequate supply from local utility (PDAM).

TABLE XII. COMMUNNITY SATISFACTION TOWARDS WATER

\begin{tabular}{|c|c|c|c|}
\hline No & Evaluation & $\begin{array}{c}\text { Number of } \\
\text { Respondents }\end{array}$ & $\begin{array}{c}\text { Percentage } \\
\%\end{array}$ \\
\hline 1 & Satisfactory & 30 & 15 \\
\hline 2 & Good & 50 & 25 \\
\hline 3 & Fair & 70 & 35 \\
\hline 4 & Poor & 50 & 25 \\
\hline & Total & 200 & 100 \\
\hline
\end{tabular}




\section{2) Drainage}

Based on the survey results in the study area that the existing drainage network is not working so that there is sometimes flooding in rainy season

TABLE XIII. COMMUNNITY SATISFACTION TOWARDS ROAD DRAINAGE SYSTEM

\begin{tabular}{|l|l|c|l|}
\hline No & Evaluation & $\begin{array}{c}\text { Number of } \\
\text { Respondents }\end{array}$ & $\begin{array}{c}\text { Percentage } \\
\%\end{array}$ \\
\hline 1 & Satisfactory & 30 & 15 \\
\hline 2 & Good & 30 & 15 \\
\hline 3 & Fair & 70 & 35 \\
\hline 4 & Poor & 70 & 35 \\
\hline & Total & 200 & 100 \\
\hline
\end{tabular}

\section{3) Sanitation}

Based on the survey in the study area, residents already have their own sanitation facilities in their house. There are only a few sanitation facilities that has not meet the minimum standard because using improper cover material.

TABLE XIV. COMMUNNITY SATISFACTION TOWARDS COMMUNAL SANITATION FACILITIES

\begin{tabular}{|l|l|c|l|}
\hline No & Evaluation & $\begin{array}{c}\text { Number of } \\
\text { Respondents }\end{array}$ & $\begin{array}{c}\text { Percentage } \\
\%\end{array}$ \\
\hline 1 & Satisfactory & 30 & 15 \\
\hline 2 & Good & 60 & 30 \\
\hline 3 & Fair & 50 & 25 \\
\hline 4 & Poor & 60 & 30 \\
\hline & Total & 200 & 100 \\
\hline
\end{tabular}

\section{4) Municipal waste management}

The movement of sub-Vera-cruz sub-district and out-oftown immigrants, in the city centers such as workplaces, schools, shopping centers, places of worship, and center of culture result in the generation of garbage municipal waste. Unfortunately, there are some citizens unaware with waste services provided by the local government and dispose waste illegally.

TABLE XV. COMMUNNITY SATISFACTION TOWARDS MUNICIPAL

\begin{tabular}{|c|c|c|c|}
\hline No & Evaluation & $\begin{array}{c}\text { Number of } \\
\text { Respondents }\end{array}$ & Percentage $\%$ \\
\hline 1 & Satisfactory & 50 & 25 \\
\hline 2 & Good & 60 & 30 \\
\hline 3 & Fair & 50 & 25 \\
\hline 4 & Poor & 40 & 20 \\
\hline & Total & 200 & 100 \\
\hline
\end{tabular}

B. Community Participation Analysis in Settlements Improvement of Dili

In this research, community participation to improve settlements in Dili (sub District Vera-Cruz) can be analyzed from ten variables, as follows: organizational form, organization activity, membership in organization / community activity, attendance in meeting, donations, reconstruction and maintenance of residential houses, maintenance of public facilities, improvement of settlement infrastructure, social attitudes, and government programs.
a. Type of entities/organization
b. Type of organizational activity
c. Organizational participation
d. Attendance
e. Donation

Furthermore, assessment variable in the improvement and maintenance of the settlement in the study area can be seen in the following table:

TABLE XVI. COMMUNITY BASED EVALUATION TOWARDS ASSOCIATION MEMBERSHIP

\begin{tabular}{|c|c|c|c|}
\hline No & Parameter & $\begin{array}{l}\text { Number of } \\
\text { Respondent }\end{array}$ & $\begin{array}{c}\text { Percentage } \\
(\%)\end{array}$ \\
\hline 1. & $\begin{array}{l}\text { Type of entities/organization } \\
\text { - Profit organization } \\
\text { - } \quad \text { Non profit organization } \\
\text { - Informal organization }\end{array}$ & $\begin{array}{l}38 \\
79 \\
83 \\
\end{array}$ & $\begin{array}{c}19 \\
39,5 \\
41,5\end{array}$ \\
\hline 2. & $\begin{array}{l}\text { Type of organizational } \\
\text { activity } \\
\text { - Economic } \\
\text { - Social } \\
\text { - Art \& culture }\end{array}$ & $\begin{array}{l}43 \\
87 \\
70\end{array}$ & $\begin{array}{c}21,5 \\
43,5 \\
35\end{array}$ \\
\hline 3. & $\begin{array}{l}\text { Organizational participation } \\
\text { - } \quad \text { On their own } \\
\text { - } \quad \text { Being forced } \\
\end{array}$ & $\begin{array}{l}96 \\
64 \\
40 \\
\end{array}$ & $\begin{array}{l}48 \\
32 \\
20 \\
\end{array}$ \\
\hline 4. & $\begin{array}{ll}\text { Attendance } \\
\text { - } & \text { Always }(>75 \%) \\
\text { - } & \text { Frequently }(50-75 \%) \\
\text { - } & \text { Rarely }(<50 \%)\end{array}$ & $\begin{array}{l}96 \\
64 \\
40\end{array}$ & $\begin{array}{l}48 \\
32 \\
20\end{array}$ \\
\hline 5. & \begin{tabular}{ll}
\multicolumn{2}{l}{ Donation } \\
- Ideas \\
- $\quad$ Money or materials \\
- $\quad$ Actions \\
\end{tabular} & $\begin{array}{l}82 \\
47 \\
71\end{array}$ & $\begin{array}{c}41 \\
23,5 \\
35,5\end{array}$ \\
\hline
\end{tabular}

The table above indicates that there is low effort in rehabilitation and improvement of settlement in terms of community participation. They tend to take part in informal organization about socio-culture and family because of their belief that it is more accepted by society rather than participatin in donations for urban infrastructure improvement \& rehabilitation.

\section{Analysis of the Improvement of Settlements in Selected Study Area}

Hal ini tentunya dilandasi oleh pengetahuan dan kesadaran, sedangkan peningkatan pengetahuan dilandasi oleh meningkatnya pendidikan baik formal maupun non formal. Dalam hal ini, variabel yang diteliti meliputi: perbaikan dan pemeliharaan rumah tinggal, perbaikan dan pemeliharaan sarana permukiman, perbaikan prasarana permukiman, sikap sosial, dan program pemerintah.

Restoration of settlements is not limited to permanent housing, but more importantly it meets the minimum health standard, where the house is clean, properly arranged, good facilities / infrastructure (ventilation, sewerage, multifunctional space), healthy living environment, etc. In addition, community should be able to understand the importance of healthy lifestyles and living environment, and how to address the problems arise in the society.

This is certainly based on knowledge and awareness obtaining from formal and non formal education. In this case, variables being studied include rehabilitation and 
maintenance of residential houses, rehabilitation and maintenance of public facilities, rehabilitation and maintenance of urban infrastructure, society support, and government programs.

Furthermore, variable in the improvement and maintenance of the settlement in the study area can be seen in the following table:

TABLE XVII. COMMUNITY BASED EVALUATION TOWARDS URBAN REHABILITATION IN SUB DISTRICT VERA-CRUZ

\begin{tabular}{|c|c|c|c|}
\hline No & Evaluation Parameter & $\begin{array}{l}\text { Number of } \\
\text { Respondent }\end{array}$ & $\begin{array}{c}\text { Percentage } \\
(\%)\end{array}$ \\
\hline 1 & $\begin{array}{l}\text { Rehabilitation \& maintenance of } \\
\text { housing } \\
\text { - Self funded } \\
\text { - Local residents help } \\
\text { - } \quad \text { Government-funded }\end{array}$ & $\begin{array}{l}53 \\
82 \\
60\end{array}$ & $\begin{array}{c}26,5 \\
43,5 \\
30\end{array}$ \\
\hline 2 & $\begin{array}{l}\text { Rehabilitation \& maintenance of } \\
\text { public facilities } \\
\text { - Routine } \\
\text { - Periodically } \\
\text { - Incidental }\end{array}$ & $\begin{array}{l}57 \\
51 \\
92\end{array}$ & $\begin{array}{c}28,5 \\
25,5 \\
46\end{array}$ \\
\hline 3 & $\begin{array}{l}\text { Rehabilitation \& maintenance of } \\
\text { housing urban infrastructure } \\
\text { - Routine } \\
\text { - Periodically } \\
\text { - Incidental }\end{array}$ & $\begin{array}{c}50 \\
50 \\
100\end{array}$ & $\begin{array}{l}25 \\
25 \\
50\end{array}$ \\
\hline 4 & $\begin{array}{l}\text { Society support } \\
\text { - } \quad \text { Very supportive } \\
\text { - } \quad \text { Supportive } \\
\text { - } \quad \text { Less supportive } \\
\end{array}$ & $\begin{array}{l}57 \\
89 \\
54 \\
\end{array}$ & $\begin{array}{c}28,5 \\
44,5 \\
27\end{array}$ \\
\hline 5 & $\begin{array}{l}\text { Government program } \\
\text { - } \quad \text { Highly oriented in local needs } \\
\text { - } \quad \text { Oriented in local needs } \\
\text { - } \quad \text { Less oriented in local needs }\end{array}$ & $\begin{array}{l}34 \\
80 \\
86\end{array}$ & $\begin{array}{l}17 \\
40 \\
43\end{array}$ \\
\hline
\end{tabular}

The table indicates that the respondents' assessment that leads to improvement in the residence is expecting the government's assistance. This is also due to socio-economic community that is below the poverty line, although there are also people who are able to repair their homes by handing to others. Thus, sub-district of Vera-Cruz can be said as slum. Communities tend to consider that it is government duties to maintain urban infrastructure. However, based on the discussion with Cefe de Aldeia/RT, they are still willing to contribute in the rehabilitation of public facilities, such as drainage system, hall, sport center.

\section{Evaluation of Community Partisipation in the Settlement Rehabilitation and Reconstruction}

Basicly, the improvement of villages in Dili is an implementation towards city maintenance program conducted by Dili district government which runs based on proposed ideas by residents. Residents would like to improve their living environment with guidance from Dili local government to resolve precisely non-technical / social problems that may arise.

Thus, all steps and policies of settelement improvement undertaken by the Dili district government are directed to improve the physical infrastructure of the settlement environment by involving local residents.

Priority facilities that must be improved based on an assessment of the level of community satisfaction with a sufficient and highly satisfactory indication below $60 \%$ are:
- Transportation

- Education

- Worship

- Public facilities and green open spaces

- Clean water

- Drainage system

- Sanitation

- Municipal waste management

Community unawareness towards their urban living environment shown by the existence of urban-slum dwellers. However, they believe that this is common situation because of poor level education. In fact, it is potentially beneficial that the proportion of male is bigger than female, so that they could take part in rehabilitation and improvement of settlement through their membership in informal organization.

\section{CONCLUSION}

From the research, it is concluded that there are several aspects of infrastructure in the improvement of settlement conditions that must be prioritized because of low level satisfaction of services stated by community. Aspects of these infrastructures are (1) Transportation; (2) Education; (3) Inventory; (4) Public facilities and green open spaces; (5) Clean water; (6) Drainage; (7) Sanitation; and (8) Garbage.

Based on the evaluation results, the state of community participation in the improvement of urban settlements is low because there is tendency of the community preferring to participate in informal organizations engaged in the field of socio-cultural and family gathering which is categorized as non-profit organization on the sense of high acceptance by the local community.

Community participation in the improvement and development of urban settlement can not well accomplished because of poor economic condition, which they can not afford to give donation. On the other hand, in terms of human resources, there is still people who are willing to engage and take a part. Informal organization they are participating in is good start for contributions in the improvement and development of urban settlement.

Improvement of the settlement based on community participation can be well established by promoting in improving understanding of good urban settlement. It is known from the fact that living in slum is something common (feels enough with what they have). Integrated cooperation among stakeholders including government, private sector, and community in formulating programs for improvement of the urban settlement environment is urgently needed. It is concluded from the result of evaluation and assessment of community participation in the development of the city of Dili which is quite low.

\section{REFERENCES}

[1] Adi dan Rukminto Isbandi, (2008), Intervensi Komunitas Pengembangan Masyarakat Sebagai Upaya Pemberdayaan Masyarakat, Raja Grafindo Persada, Jakarta..

[2] Alit, IK (2005), Pemberdayaan Masyarakat dalam Peningkatan Kualitas Permukiman Kumuh di Propinsi Bali, Jurnal Permukiman Natah Vol. 3 No. 1 Februari 2005. 
[3] Allo S , Johan Silas, Rimadewi Supriharjo. (2010). Konsep Optimalisasi Program Perbaikan Kampung Melalui Peningkatan Partisipasi Mayarakat di Kota Makassar.Surabaya: Jurnal Jurusan Arsitektur - FTSP - ITS Surabaya

[4] Azizah,et.al, 2006,Grand Desain Peningkatan Kualitas Hidup Masyarakat Miskin di Sepanjang Kawasan Bantaran Sungai di Jawa Timur,Bacon, Edmund, N, 1978, Hasil Penelitian

[5] Hakim Rustam, dkk, 2008. Persepsi Masyarakat Terhadap Aspek Perencanaan RTH Kota Jakarta. FALTL Universitas Trisakti. Jakarta.Budihardjo Eko dan Hardjohubojo Sudani (1993), Kota Berwawasan Lingkungan, Penerbit Alumni, Bandung

[6] Budihardjo, Eko, 1999, , Penguin Books, New York. Kota Berkelanjutan,

[7] Catanese, Anthony James dan James C. Snyder. 1988. Perencanaan Kota,Terjemahan Ir. Wahyudi. Jakarta: Penerbit Erlangga.

[8] Herawatty dan Ratna (2006), Strategi Peningkatan Partisipasi dalam Pengelolaan Jaringan Irigasi, Thesis, Magister Teknik Arsitektur yang tidak dipublikasikan, FTSP-ITS, Surabaya.
[9] Murdoch. 1994. Community Participation in Practice Casebook. WesternAustralia: The Institute for Science and Technology Policy.

[10] Nazir Moh. 1999. Metode Penelitian. Jakarta: Ghalia Indonesia.

[11] Ndraha Taliziduhu. 1983. Partisipasi Dalam Pembangunan. Jakarta: LP3ES

[12] Oetomo. 1980. Partisipasi Masyarakat Dalam Pembangunan Sosial Jakarta:Ghalia Indonesia.

[13] Rolalisasi Andarita (2008), Pola partisipasi masyarakat dalam Perbaikan Kawasan Permukiman Kumuh di kelurahan Sukolilo Kecamatan Bulak Kota Surabaya, Thesis, magister Teknik Arsitektur yang tidak dipublikasikan, FTSP-ITS, Surabaya.

[14] Silas Johan, (1992), Kampung Surabaya Menuju Metropolitan, Yayasan Keluarga Bhakti Surabaya dan Surabaya Post 